This Version: October 8, 2020

\title{
CORRELATES OF CRISIS INDUCED CREDIT MARKET DISCIPLINE: THE ROLES OF DEMOCRACY, VETO PLAYERS, AND GOVERNMENT TURNOVER
}

\author{
Puspa D. Amri (Assistant Professor, Sonoma State University) \\ Eric M.P. Chiu (Associate Professor, National Chung Hsing University) \\ Jake M. Meyer (Claremont Institute for Economic Policy Studies) \\ Greg M. Richey (Assistant Professor, University of California, Riverside) \\ Thomas D. Willett (Horton Professor of Economics, Claremont Graduate University and \\ Claremont McKenna College $)^{1}$
}

\begin{abstract}
Do countries learn from their mistakes? Here we consider one example of this question with respect to banking crises using the concept of effective learning, that is learning plus the ability to implement such learning. Excessive credit growth is widely considered to be the most important contributor to banking crises. Thus, it is interesting to see whether banking crises are associated with lower rates of credit growth in the future and if so, what are major factors which influence such changes in behavior. In previous research we have found that on average banking crises are followed by substantially lower rates of credit growth but this varies considerably across countries. Our hypothesis is that lower rates of future credit growth reflect a process of learning from one's mistakes and taking corrective actions. This paper offers an investigation of some of the political economy factors that may influence whether crises result in greater discipline over future credit growth. Overall, we found very little average effective learning in stable autocracies and on the contrary, found considerable discipline in stable democracies; nevertheless, we found even larger discipline effects in countries that transitioned to democracy during and in the wake of a banking crisis. Our results regarding the role of veto players and government turnovers are inconclusive.
\end{abstract}

\footnotetext{
${ }^{1}$ All of the authors are also associated with the Claremont Institute for Economic Policy Studies. We thank Mark Copelovitch, Andreas Kern, David Steinberg and Meredith Wilf for valuable comments and suggestions.
} 


\section{Introduction}

Do crises lead to learning by countries and provide discipline over the behavior of the factors that caused the crisis in the first place? Here we explore one aspect of this question, focusing on banking crises. To have such discipline it is necessary to have not only learning but the ability to implement changes based on this learning. We call this concept effective learning. Excessive credit growth is widely considered to be the most important contributor to banking crises. ${ }^{2}$ Thus, it is interesting to see whether banking crises are associated with lower rates of future credit growth, and if so, what are major factors which influence such changes in behavior. In other words, do financial crises tend to generate discipline over future rates of credit growth? It is clear that this does not always occur. Repeated crisis episodes in the same country (e.g., Argentina, Mexico, Thailand) clearly demonstrate that countries as a collective do not always learn from mistakes but there are also examples where the painful experiences of severe banking crises can increase the incentives for policy makers to improve the quality of their policies. South Korea, Thailand and Indonesia after the Asian Crisis of 1997-98 are examples. Thus we clearly need a large $\mathrm{N}$ study to investigate the relative frequency of such cases. In earlier work, Amri et al. (2017), we found evidence of substantive learning on average from banking crises but that there were considerable differences across countries. Why there were such differences is an important issue. This paper offers an investigation of some of the political economy factors that may influence whether banking crises result in greater discipline over future credit growth.

To correct behavior, actors must not only learn from mistakes but also be able to implement changes in behavior. Countries are not unified rational actors. There are many actors that may influence to what extent countries do learn from crises and adopt better policies for the future. Some actors may learn but not have the power to implement needed reforms. At this stage of large $N$ analyses, we can only investigate effective learning i.e., learning by actors that are able to implement learning into policy changes. ${ }^{3}$ For example, public pressure may lead elected governments in democracies to enact legislation that improves regulation and supervision of the financial sector. Monetary and financial officials may learn to improve how they implement their supervision. Furthermore, the financial sector actors may see

\footnotetext{
2 Note that this assertion applies to banking crises. See e.g., Schularick and Taylor (2012), Drehman and Yetman (2018), Gennaioli and Shleifer (2018). For other types financial crises such as currency crises, credit growth plays a less central role compared to foreign reserves or real exchange rate misalignments.

${ }^{3}$ A complete analysis would go well beyond the scope of any one paper and would include careful case studies of many possible channels of learning by different agents as has been done by scholars with respect to some types of policy learning in specific cases. At this stage, we are not able to distinguish among these disaggregate channels that affect changes in public and private sector policies, but only by the composite effects of learning and implementation.
} 
that it is in their interests to improve their internal capacity to manage their distressed credits and detect problems early on. Yet there is no guarantee that there will be sufficient effective learning. Actors often differ in their perceptions of causes of the banking crisis and special interests may block the adoption of reforms or their effective implementation. While crises may act as a push for policy reforms, the quality of the implementation is affected by the institutional and the political environment of each country (Tomassi 2004). They likely will not always be effective.

To the best of our knowledge there have been only a few large $\mathrm{N}$ studies that have investigated such possible learning behavior in the area of economic crises. ${ }^{4}$ Lim and Minne (2014) found that following the 2008 global financial crisis, foreign banks with more crisis-experience in their home countries reduced their lending to developing countries by a greater amount than foreign banks with less exposure to past crises, while as noted above we have found evidence of lower average credit growth after banking crises. Research by Aizenman and Noy (2013) suggests that a past history of crises does not make future crises less likely, while Meyer et. al. (2020) find the opposite with respect to currency crises and crashes. While looking directly at what happens to the frequency of future crises after crises occur is important we believe that is also necessary to look directly at changes in behavior that are important causes of crises. Hence the approach in this paper.

As in Amri et al. (2017), we focus on banking crises (as one type of financial crisis) and we operationalize learning by comparing the rates of credit growth that preceded banking crises with subsequent growth rates, since excessive credit growth is considered an important contributor to banking crises. Therefore, our baseline hypothesis is that banking crises are associated with lower rates of private credit growth after a banking crisis has ended. Crises themselves are generally associated with an initial sharp reduction in credit so we begin our post crisis measurements only after such initial effects have ended.

We focus on three factors that the political economy literature suggests may influence effective learning: political regimes (democracy versus non-democracies), veto players and partisan government turnovers. We find that democracies on average experience a significantly larger rate of reduction in post-crisis credit growth than non-democracies, yet this effect is only found after taking into account countries that transitioned to democracy after a banking crisis. While this suggests that political regimes are important, the channels of influence may operate through the characteristics or features of democracy itself or through the crisis-induced political regime transition. Other independent variables

\footnotetext{
${ }^{4}$ We should note that this type of analysis of effective policy learning differs from the strands of the policy learning literature that focus on the diffusion of policy ideas. See, for example, Simmons et al. (2006). Ultimately a merger of these different types of approaches would seem highly desirable.
} 
such as government turnover and veto players do not appear to have major effects, as the estimated coefficients on these variables were not robustly significant. The focus on these variables does not mean we place little importance on other political and institutional variables such as the rule of law and the strength and competence of governments. In future research, we plan to investigate variables that may impose effective learning from outside of the domestic political process, specifically the role of central bank independence, exchange rate regimes and programs with the International Monetary Fund, as well as the interactions between those factors as the IMF can play an important role in the emergence of a new regulatory regime after a banking crisis (Kern et al. 2019).

The remainder of this paper is structured in the following way. In section two, we present our approach and review the related literature on banking crisis and policy learning. In section three we discuss our data and econometric methodology. Section four presents our main statistical results. Section five concludes and offers suggestions for further research.

\section{Related Literature and Hypotheses}

\subsection{The Framework}

Few gain from banking crises. Thus it seems safe to assume that such crises are often the unforeseen consequences of policies followed by the public and private sectors. A banking crisis should thus foster reevaluations of relationships that may have contributed to these unforeseen disasters. Such crises frequently may have been foreseen by some actors as was the case with the 2007 U.S. subprime crisis but those who warned of the likelihood of the looming crisis were few and had little influence. The prevailing view was that innovations in risk management had made the U.S. financial system extremely safe.

The crisis generated a substantial reevaluation of such views. The major causes of crises are not always clear, however, and often those from different political or theoretical camps draw different conclusions about what factors were most important. Indeed in the case of the US subprime crisis, over thirty contributing factors have been identified ${ }^{5}$ with many on the right focusing heavily on the role of government policies such as the affordable housing acts while many on the left have attributed blame to financial deregulation. Many economists in the middle have focused on factors such as unrealistic expectations of continued growth in housing prices, excessive reliance on faulty risk management systems, lax enforcement of regulations, and perverse incentive structures such as moral hazard and the payment structure for the ratings of securities (Angelides and Thomas 2011).

\footnotetext{
${ }^{5}$ See Davies (2010).
} 
While few have incentives to follow policies that they know will generate crises, many gain benefits from the pursuit of policies such as easy credit growth and lowering of loan standards that carry risk of generating crises (Kern and Amri 2020). The greater are these gains and the lower the perceived probability of their generating a crisis, the more likely are actors to pursue such policies, even though some may recognize the potential adverse consequences thereafter. Furthermore, while profits are rolling in, confirmation biases may often lead actors to discount warning signs of increasing danger of crises. Such wishful thinking can affect regulatory officials as well as private sector actors.

The time dimension can also be important. If private sector financial managers can make sufficient gains in the pre-crisis period then they may come out ahead even if they suffer major losses during the crisis itself, much less if they were able to pull out before the crisis occurred. Likewise, with politicians, forcing a substantial tightening of credit will undoubtedly be unpopular with a majority of voters (Antoniades and Calomiris 2020) so they have incentives to postpone such policies if a crisis does not appear imminent, especially before the next election. Moreover, it also takes time for loan performance problems to appear, and thus during the credit expansionary phase, risk-related statistics may be of little use in signaling problems ahead of time (Berger and Udell 2004). Lastly, rapid credit growth could also be capturing more financial deepening rather than a credit bubble (Mendoza and Terrones 2012), and thus another source of uncertainty.

The substantial uncertainties involved may curb the incentives of both public and private sector actors to take prudent actions and radical uncertainty commonly clouds the situations leading up to crises. ${ }^{6}$ Contributing to this uncertainty is that not all episodes of high credit growth lead to a crisis (Amri et al. 2012, Aldasaro et al. 2018) ${ }^{7}$. Still, as earlier discussed, rapid credit growth is probably the most common cause of banking crises, especially for advanced economies (See e.g., Schularick and Taylor (2012)), and hence our focus on it in this paper. We could think of credit booms largely as necessary but not sufficient conditions for banking crises.

The literature on cognitive psychology that is now beginning to be incorporated in behavioral economics, finance and political economy stresses the tendency of many individuals to have short time horizons leading to time inconsistency problems and the propensity of individuals to interpret reality in ways that they would like it to be. Thus if they are gaining from loose lending and rapid credit creation many are likely to have a tendency to believe arguments that this time is different and serious risks are

\footnotetext{
${ }^{6}$ On the importance of radical uncertainty with respect to financial crises, see Kay (2015) and King (2016).

${ }^{7}$ A study by the Bank of International Settlements on banking crises found many instances of unusually high credit-to-GDP ratios combined with high property prices and household debt that were not followed by a financial crisis (Aldasoro, Borio and Drehman 2018).
} 
not being run. And even when learning is fairly widespread collective action problems such as a large number of veto players could make effective reforms difficult to implement. Many voters will often not be well informed or even misinformed on complicated issues such as financial policy. Policies to slow down credit growth will often decrease or lower the performance of the economy in the short run even though they will be associated with making future crises less likely and better economic performance over the longer term. In the face of short-term horizon this can generate serious time inconsistencies problem similar to the literature on political business cycles. Given the complexity of the connection between current rates of credit growth and the probability of future financial crises, such risks seem unlikely to be salient for many voters.

Such considerations can create strong obstacles to the implementation of the reforms advocated by well-informed experts who have learned from previous crises. ${ }^{8}$ On the other hand, the crisis may have at least partially discredited such special interest groups and reduced their political clout. Such considerations suggest that the extent to which learning from crises will influence policy will depend in part on the operation of the political system.

\subsection{The effects of political regimes, veto players, and government turnovers on policy learning from financial crisis}

What is effective learning?

As discussed earlier, we define effective learning as learning by a composite of different actors (public and private) who are able to incorporate lessons learned into policy and behavioral changes, either as a result of public pressure or due to a weakening of certain interest groups that favor rapid credit growth. Therefore, our concept of learning is distinct from that used in most of the literature on policy learning and policy diffusion. For example Simmons et al. (2006) state that "learning refers to a change in beliefs or change in one's confidence in existing beliefs, which can result from exposure to new evidence, theories or behavioral repertoires” (p. 795). ${ }^{9}$ For such learning to lead to changes in policy and in private sector behavior this is a necessary but not sufficient condition. For example, experts may learn from a crisis but be unable to affect changes in public policies due to differences in popular views or pressures from special interests.

\footnotetext{
${ }^{8}$ It is often pointed out that that the character of financial crises typically vary from case to case but there are also frequent regularities that provide markers for the development of vulnerable situations. See, for example, Reinhart and Rogoff (2009).

${ }^{9}$ Other empirical tests of this concept of learning applied to economic reform include Meseguer (2006), Gilardi (2010) and Gandrud (2013).
} 
Here we focus on the case of banking crises. Gandrud (2013) found that banking crises often lead to a convergence of financial supervisory models that are heavily promoted internationally, such as a unified financial supervisory framework. (See also Amri et al. (2017), Denk and Gomes (2017), and Masciandaro and Romelli (2018)). In this study we investigate whether such changes are successful in providing effective discipline over future credit growth. It is plausible, but not a certainty, that discipline over future credit growth after a crisis could occur because the crisis changed people's views about the costs of rapid credit growth, or that a credit bust prompts bank managers to put more attention towards agency problems and improve their internal ability to differentiate between low-quality and high-quality borrowers (Udell and Berger 2004).

Given the above, an important mechanism through which effective learning from crises can take place is by enacting reforms to strengthen the financial regulatory and supervisory system, as weak (enforcement of) financial supervision often contributed to allowing credit growth to be excessively high prior to the crisis. Financial crises can make reforms more likely as a crisis can unmask weaknesses in the prevailing financial oversight (see e.g., Waelti 2015). The adverse consequences of financial crises may lead to greater public awareness of financial regulatory issues, generating more political will on the part of policymakers to overcome interest group pressures and improve financial governance infrastructures (Rosas et al. 2013).

One example of how financial reform induces learning can be seen in the 1994 banking crisis in Mexico. After the crisis, the National Banking Commission, was given more authority to sanction imprudent banks and raised capital requirements to be proportional to the riskiness of banks' assets, contributing to a more stable rate of credit growth after the crisis ended (Calomiris and Haber 2014). Likewise, the U.S. subprime crisis led to major regulatory reforms.

However, the effectiveness of these crisis-induced reforms has often been subject to debate. ${ }^{10}$ Effective learning requires not only that reforms be implemented but also that the reform themselves (i.e., the regulations produced after a crisis) are effective in meeting the goals of the reform. Thus we focus here on an outcome variable, the rate of credit growth following crises. This is a composite measure which indicates whether effective learning has taken place. Further study will be required to attempt to determine the various mechanisms through which this effective learning has taken place or been suppressed.

\footnotetext{
${ }^{10}$ For example, Moschella and Tsingou (2013) argue that the Global Financial Crisis in 2008 only brought about incremental (rather than sweeping) reforms of international standards of financial regulations. Mian et al. (2014) found that while financial crises lead to reforms, the magnitude of these reforms are not substantively significant, or lack economic importance.
} 
In our earlier work we found that on average such effective learning did take place but that there was considerable variation across countries so here we begin an investigation of possible factors that may have influenced these variations. We focus on three domestic political and institutional factors that may contribute to effective policy leaning and implementation resulting in lower future credit growth. These are political regime types (democracies versus autocracies), the number of veto players in the political system, and government turnovers. Below we discuss the main channels through which these factors may influence future credit growth following crises.

\subsubsection{Democracy}

There is a sizeable literature on the effects of different types of political regimes on the likelihood of policy reforms (e.g., Drazen 2002, Giuliano et al 2013, Rodrik 2000). A sub-set of that literature focuses on whether democracies are more likely than autocracies to deliver good policy responses that help to correct past mistakes and internalize lessons from past financial crises (e.g., Bordo 2007, Cavallo and Cavallo 2010, Rodrik 1999). The arguments and empirical evidence both point to a mixed picture. This is understandable as democracy has many different features, some of which make such countries more likely to facilitate financial reform (and by extension facilitate learning from banking crises), while others have the opposite effect.

One feature of democracy considered conducive for economic reforms is the presence of mechanisms for consensus building. That is, participation, consultation and bargaining in democracies help forge a consensus to undertake necessary reforms (Rodrik 1999). This can be important in times of crisis as citizens look to their leaders to adopt solutions. For example, in South Korea, following the 1997 Asian Crisis, President Kim Dae Jung held several town meetings and discussions with union leaders and other groups in society, which helped build a consensus for reform, some of which would be quite painful, such as raising interest rates and contracting the economy in order to strengthen the exchange rate. At the same time, policy-making in democracies is often deliberative and timeconsuming, which is not ideal when quick decisions need to be made about crisis resolutions (although there are no guarantees that expedited decision-making makes for more sound policies). In the same spirit, while democracies are more likely to have voices of their citizens heard (Cavallo and Cavallo 2010), if the predominant voice to which government officials pay attention is that of special interest groups who oppose reform (bankers who oppose more stringent capital requirements, for example), then there may be little or no economic reform. After all, the logic of collective action suggests that small, well-organized groups have greater incentives to be informed and lobby for action (i.e., having their 
voices "heard" more loudly) than the general public who may be rationally uninformed and have lower incentives to be politically active. This rationale is supported by Yu (2005), who investigated the link between democracy and one area of economic reform, trade liberalization. Arguing that concentrated interests are better represented in democratic systems than in autocratic ones, Yu (2005) found that more democratization leads to more protectionist trade policies, which is the opposite of economic reform.

Indeed, the literature on political economy of reform highlights the role of interest group pressure as an important constraint on economic reforms that would limit their rent-generating activities (see e.g., Giuliano et al. 2013 for a review). However, which type of political regime is better able to resist interest group pressures is not widely agreed upon.

Some think the answer is democratic regimes, as policymakers there are more accountable to the voters in general (the "public"), and should therefore be more willing to implement reforms that favor the general interests over the interests of narrow groups who benefit from status-quo policies (Cavallo and Cavallo 2010, Giuliano et al. 2013). Bardhan (1998) showed that after the 1991 balance of payments and currency crisis in India, the government pushed through with substantial economic reform despite strong vested interests that benefited from financial repression. Giuliano et al. (2013) analyzed 150 countries over the 1960-2004 period and find that democracy leads to positive changes in six areas of economic reform (domestic finance, capital account, product markets, agriculture, trade, and current account transactions).

On the other hand, interest groups may be more mobilized and influential in democracies, which means that these groups can have greater power to limit reforms. As Mexico became more democratic, for example, many of the reforms that were instituted in the mid 1990s were later weakened by special interest groups (Haber and Mussacchio 2013).

Unlike their authoritarian counterparts, democracies have competitive elections, and this too has arguments that cut in opposite directions. On the one hand, the desire to win votes can lead the government to side with pro-reform groups and push back against the narrow interests of the banking sector. As an example, Rosas (2009) show that electoral competition led to crisis-response policies that shift the burden of the crisis largely on the bankers' side, which minimized the burden on taxpayers in general. ${ }^{11}$ Studying a panel of 78 countries with data for years 1970-2004, Cavallo and Cavallo (2010)

\footnotetext{
${ }^{11}$ The choice for who bears the cost for banking crises is often presented is one between bankers (the so-called Bagehot model) and taxpayers (bailout model). In contrast to Rosas (2009), Chwieroth and Walter (2020) found that the pattern has reversed in more recent decades, and democratic regimes are more likely to adopt the bailout model, due to pressures from the middle class who have growth increasingly dependent on financial wealth.
} 
find that political competition ${ }^{12}$ dampens the negative effects of banking crises on long-term growth. On the other hand, electoral pressures combined with time-inconsistency problems may give governments in democracies stronger incentives to delay necessary adjustments (Amri and Willett 2017). This could be particularly true if the reforms or adjustments in question have uncertain effects. ${ }^{13}$ Indeed, incumbent governments may try to avoid this political risk by delaying actions in the face of upcoming elections (Keefer 2001).

Since banking crises often lead to improvements in democracy scores (e.g., Mexico 1994) or outright transitions to democracy from authoritarian regimes (e.g., Argentina 1980 and Indonesia 1997), it is also worth asking whether regime transitions may play a role in influencing post-crisis outcomes. Democratic transitions introduce competitive elections (a break with authoritarian-style elections), which then prompts a "new" crop of political elites courting voters with reforms. This could improve post-crisis outcomes. On the other hand, populism could lead to pressures for increased government spending and easing access to credit. ${ }^{14}$ The timing of the measurement of democracy matters. In a large $\mathrm{N}$ study of the effects of banking crises on democratic improvements, Kouevi-Gath et al. (2019) found that most of the increases in democratic scores do not occur until three to 10 years after the start of a banking crisis. We will investigate both the nature of the political regime at the onset of the crisis and the effects of transitions to democracy.

In sum, both theoretical arguments and empirical evidence show that democracy can have either positive or negative effects on economic reform. In the first step of this study we investigate whether one or the other of these forces tends to dominate. It is clear from the case studies that democracies may differ substantially and thus there is need for more comprehensive contingent research that focuses on the attributes of democracies that may influence the balance of pressures. One likely candidate is the number of institutional and partisan actors (veto players) whose consent is necessary to change status quo policies (Tsebelis 2002). The relationship between veto players and economic reform is discussed in the next section.

\subsubsection{Veto Players}

\footnotetext{
${ }^{12}$ A high index of political competition (taken from the Polity IV dataset) means that the country has "relatively stable and enduring political groups that regularly compete for political influence” and that there are no prohibitions on oppositional activity (Marshall et al. 2018).

${ }^{13}$ Rodriguez and Rodrik (2000) show that uncertainties about the benefits of economic reforms could lead to people blocking reform altogether.

${ }^{14}$ See e.g. Kern and Amri (2020) for examples of populism and credit-expansion policies prior to elections.
} 
Veto players — institutional actors whose consent is needed to change policy — function as a check on discretionary policy-making powers of the executive, an important part of a democracy. Since most major economic policy reforms must pass through the legislature, the number of and uniformity of preferences among the different veto players can importantly affect the likelihood of these reforms. By and large, scholars tend to agree that multiple veto players with distinct preferences - while ensuring that different viewpoints and interests are represented - make it more difficult to implement policy reform (e.g. Tsebelis 2002, Cox and McCubbins 2001), since it only takes one veto player with a partiality to certain anti-reform groups to block proposed policy reform. Although special interest groups have no formal veto powers, they often lobby legislative members to implement particularistic policies at the expense of public-regarding policies, such as anti-reform policies (Gelbach and Malesky 2010). The higher the number of veto players, the more avenues there are for these anti-reform interests to block actions (Cox and McCubbins 2001). Consequently, on this argument that more veto players should reduce the probability of substantive economic reforms, we would expect to see them associated with smaller reductions in post crisis credit growth.

This argument, however, does not fit with the experiences of some Eastern European countries in the 1990s. For example, Croatia and Poland achieved notable economic reforms (e.g. privatization, establishment of independent bank regulators) as these countries moved from semi-presidential to parliamentary systems in the 1990s (Gelbach and Malesky 2010), despite a system with a higher number of veto players. Murillo and Martinez-Gallardo (2007) document a similar positive relationship between the number of veto players and market reform in Latin America. ${ }^{15}$

It seems quite possible that the relationship between the number of veto players and economic policy reforms that increase efficiency may be non-linear. With a low number of veto players, chief executives have more power to initiate reform, but such chief executives likely will be more insulated from societal pressure for reform, due to lack of checks on their executive power. When reforms are attempted by crisis-hit countries in such an environment, such as Indonesia and Malaysia in 1998, they

\footnotetext{
15 There is an argument made by Gelbach and Malesky (2010) that multiple veto players could actually weaken interest groups (the opposite of Cox and McCubbins' argument) as each actor must now bargain harder for the policies that they prefer with more veto players to compensate in the political system. This argument does not apply directly in our context, however, since we are dealing with cases of trying to weaken the former power of special interests while their argument would seem to apply to the difficulties of special interests increasing their rent- generating positions. A possibly negative correlation between the number of veto players and the strength of special interests has also been suggested by Keefer (2001), although his reason is quite different. With more veto players, pay-offs from narrow groups are distributed over a larger number of decision-makers, thus "the attractiveness of authorizing benefits to special interests falls" (Keefer 2001, p. 6), and voices of those that oppose reform become somewhat suppressed.
} 
often tend to be partial and incomplete, and sometimes create more investor panic (MacIntyre 2001). ${ }^{16}$ On the other hand, with a large number of veto players, pressures to reform may be stronger, but there are more actors who could block reform. Indeed, MacIntrye (2001) hypothesized a quadratic relationship between veto players and economic policy, one where an intermediate number of veto players is most conducive for economic policy reform and investor confidence. Consistent with this hypothesis, the Philippines, with an intermediate level of veto players, had a better track record in minimizing the disruptive effects of the 1997-98 financial crisis on investor confidence than Thailand, with a high count of veto players or Indonesia, and Malaysia with few veto players. For a large $N$ study of emerging markets, Angkinand and Willett (2008) applied McIntyre's hypothesis to test the influence of veto players on output losses associated from banking crises. They found that both too high and low numbers of veto players were associated with greater output losses from banking crises.

To summarize, just as there reasons for democracies to be more or less likely to lead to postcrisis policy reforms, there are arguments in either direction for veto players as well. As the above review suggest that veto players have a direct effect on policy reform, in the empirical section, we test whether there is a significant relationship between veto players and the reduction in credit growth after a banking crisis. However, it is also plausible for veto players to operate indirectly by moderating the effects of democracy on post-crisis credit growth. For example, between two countries of equal levels of democracy, one with a higher count of veto players may find it more difficult to enact post-crisis financial reform and as such, we should see less of an effective learning effect. Thus we test whether there is a significant difference in the reduction of credit growth after a crisis between democracies with relative fewer and relatively higher numbers of veto players.

\subsubsection{Government Turnovers}

Financial crises are often followed by changes in leadership or substantial declines in the vote share of incumbent parties (e.g., Bartels 2011, Pepinsky 2012, Lewis-Beck and Lobo 2017, Funke et al. 2016, Chwieroth and Walter 2020). That financial crises increase the probability of government turnovers is consistent with the economic voting literature: economic booms help incumbents, while economic downturns and the severe dislocations that typically accompany financial crises create strong pressure from voters to oust incumbent governments. Still, incumbents sometimes do survive a financial crisis if they can convince voters that they are better at managing the crisis compared to their opposition

\footnotetext{
${ }^{16}$ For example in the Indonesian case political connections kept the government from closing all of the weak financial institutions identified by the IMF leading to a run on some of the remaining institutions for fear that they also would be closed in the future.
} 
counterparts as occurred with the conservative government in Canada in 2008 and 2011 (Belanger and Nadeau 2014).

As discussed by Horowitz et al. (2009), government turnovers occur in both democratic and authoritarian regimes and can have important effects on economic policies and performance. Most government turnovers involve a change in the ideology of the incumbent party (from left-to-right or leftto-center and vice versa), although some cases of leadership turnover occur without changing the partisan orientation of the government (Horowitz et al. 2009). Whether a government (ideological) turnover encourages or hinders the likelihood of post-crisis reforms that are crucial for effective learning is still debatable. One the one hand, more frequent turnovers can be a source of uncertainty and instability because policies tend to change very frequently, and thus may become less credible. On the other hand, it can promote accountability and be more conducive for reform. According to Krueger (1993), one of the most important triggers for economic reforms is a turnover of government as new incumbents have an incentive to undertake reforms early on. Public dissatisfaction with the state of the economy provided substantial pressure for the new Mexican president Ernesto Zedillo to find a way to get the economy moving again and fix problems in the banking sector (Calomiris and Haber 2014). The response to the US sub-prime crisis also fits this story.

Turnovers that change the political orientation of the government (as opposed to only changes in leadership with no shift in the ideological orientation), may have a more substantive impact ${ }^{17}$ on policy reform, yet it is far from clear which type of partisan turnover (from right-wing to left-wing governments or vice versa) would be more conducive for policy reform. Past work has focused on how the ideology of the ruling government — as opposed to ideological turnovers — influences economic reforms and postcrisis policy responses (Abiad and Mody 2005, Ha and Kang 2015). Abiad and Mody (2005) analyzed financial sector policies and government ideology from 35 countries over the period of 1973 to 1996. They found that right-wing governments are more receptive to market-oriented reforms ${ }^{18}$; however, several crucial economic reforms in Latin America took place under left-wing incumbency (Cukierman and Tomassi 1998, Campello 2014). Waelti (2015) found that while both left and right chief executives

\footnotetext{
${ }^{17}$ Government turnovers that are not accompanied by changes the ideological stance would be more or less guided by the same ideological principles as the previous government and hence would not be expected to have a significant impact (Horowitz et al. 2009). This is especially relevant in many developing countries with little partisan distinction from one party to another. An example is Thailand, which had a rightist government in 1983 (led by the Chart Thai party), only to be replaced by another right-oriented administration after the crisis (the Democratic Party).

${ }^{18}$ Abiad and Mody (2005) also found that many subsequent right-wing governments were quick to reverse financial policy changes initiated by the previous government.
} 
tend to implement reforms after a financial crisis, there is a slightly stronger effect for right-oriented chief executives.

The discussion above suggests that government turnover may affect post-crisis policies, but it remains unclear which direction of turnover is more conducive for reform and effective learning from a financial crisis. Therefore, we test both for the effects of all turnovers, as well as the direction of turnovers left to right and right to left. ${ }^{19}$

\section{Data Description and Methodology}

To test the effects of our domestic political variables - democracy, veto players, and partisan government turnovers - on the rate of reduction in private credit growth after a banking crisis, we estimate an econometric equation that is similar to a difference-in-difference estimator. This technique allows us to test whether the change in post-crisis credit growth relative to pre-crisis credit growth varies conditional upon a number of independent variables. Using data spanning from 1970 to 2018, the regressions include up to 59 banking crises in 51 countries, as identified in Laeven and Valencia (2020) (the number of episodes vary depending on the model specification).

The dependent variable is the change in average rates of real credit growth from pre-crisis to post-crisis time windows. Credit growth is the change in the log of bank credit to the private sector divided by the consumer price index from the IMF's International Financial Statistics. ${ }^{20}$ We define precrisis periods as three years before the onset of a banking crisis. Because bank credit tends to fall while a crisis is underway (see e.g., Demirguc-Kunt et al. 2006), and it often takes a few further years for credit to recover to 'normal', our post crisis period is from year $t_{f}+4$ to $t_{f}+6$, where $t_{f}$ is the ending year of the crisis episode. ${ }^{21}$ Only observations with positive average credit growth in the pre-crisis years are used in the analysis, i.e., we exclude non-credit-growth-driven banking crisis episodes.

\footnotetext{
19 It should also be noted that while financial crises tends to lead to political turnovers, it is not clear whether left or rightparties are the clear winners of the political consequences of banking crises. While Broz (2013) found that the majority of governments experiencing current account crises experienced changes in partisanship (from right to left-wing), Funke et al. (2016) found the opposite result using a longer time-period of analysis. Funke et al. argue that this development underscores the rise of nationalism after a financial crisis. Bartels (2014) also found that the post-crisis performance of leftwing incumbents was relatively worse that right-wing governments.

${ }^{20}$ We used line 22d of the IFS for private credit, which is the depository corporations' claims on the domestic private credit. The IFS data was first downloaded on June 2017, and later updated in June 2020. The 2020 IFS data release retroactively updates the previous release. In some cases, the pre-crisis credit growth changed from the 2017 and 2020 download.

${ }^{21}$ Previous research suggests that it takes a few years of high credit growth to generate crises (Caprio and Klingebiel 1996, Dell'Ariccia et al. 2012) and Amri et al. (2012) find that the preceding year or two is substantively more significant in explaining banking crises. Therefore, we take a conservative approach and use a three-year window after the crisis ends for our pre-crisis period. Previous research finds that credit drops after a banking crisis tend to level off within two years (Takats
} 
The estimating equation is:

$$
\overline{\text { Credlt }}_{\text {post }}-\overline{\text { Credlt }}_{\text {pre }}=x \beta+\mu
$$

where $\overline{\operatorname{Cred} t}_{\text {post }}$ is the average real credit growth over the three years of the post-crisis period, $\overline{\operatorname{Cred}}_{\text {pre }}$ is the average real credit growth over the three years of the pre-crisis window period, $X$ refers to a matrix of the independent variables as described below and $\mu$ is the error term.

The first independent variable is democracy. Following common practice it equals one if the polity 2 index ${ }^{22}$ lists the country year as greater than +4 (from a -10 to +10 scale) at two different points in time: one year before the crisis starts and in the first year of the post-crisis window. This allows us to account for the changing nature of political regimes. In other words, we consider the regime characteristic of the country not only at the time the crisis began, but also after a crisis has ended. As it may not be democracy or autocracy alone that is the relevant factor in facilitating lower credit growth in the post-crisis period but also a transition towards democracy, we introduce a second independent variable which is democratization. This variable equals 1 if countries changed their political regimes from authoritarian to democracy between one year before the crisis starts and four years after the crisis ends, or if they experienced an increase in their polity2 score by more than 3 points. It is zero otherwise.

The third independent variable is veto players, which we operationalize using a three-year average of the political constraints (polconiii) index from Henisz (2000) during the post-crisis period (we take the average of this variable from years 4-6 after the crisis ended). This is a continuous variable ranging from zero to one, which not only counts the number of actors with veto powers (individual or collective $^{23}$ ), but also considers the degree to which these actors have their own distinct policy preferences. The higher the value, the larger the number of veto players and the more divergent are the preferences of each veto player.

To generate partisan-turnover variables, we used information from the Database of Political Institutions complemented by the Heads of Government data set by Brambor and Lindvall (2012), based

and Upper 2013) and we use a 4-year window to be conservative. Mian et al. (2014) define post-crisis spells as "up to five years after a financial crisis event.”

22 The Polity2 index is taken from the Polity IV Database, which measures democracy based on election-related indicators such as competitiveness of political participation, the openness and competitiveness of executive recruitment as well as constraints on the chief executive (Marshall et al. 2018). The break point of +4 is common in the literature (e.g., Mukherjee et al. (2014).

${ }^{23}$ An example of a collective veto player is an entire legislative chamber. For example, in the US, the president is one individual veto player. If the House of Representatives is controlled by a political party different than the president's, the entire House is a separate, collective veto player. 
on the same pre and post-crisis time periods used to measure democratic transitions: comparing the ideological orientation of the head of state one year prior to the crisis onset and four years after the crisis ends. The generated variables are: turnover (if there was a change in the ideology of the executive of any kind), the subset turnover_left (if there was a turnover from the right to the left of the political spectrum) and subset turnover_right (if there was a turnover to a right-wing government), and use the centrist ideology as basis for comparison.

\section{Empirical Results}

\subsection{Descriptive Statistics}

In this section, we present some descriptive statistics regarding our variables of interest. First, we compare pre- and post-crisis credit growth for three categories: stable democracies, stable autocracies, and democratic transitions or democratization. Comparing the state of the political regimes from pre-crisis (one year before the crisis starts) to post-crisis (four years after the crisis ends), out of the 18 autocratic regimes in the pre-crisis period, nine transitioned to democracies, while one autocratic regime became less authoritarian (Uganda, banking crisis in 1994). ${ }^{24}$ Altogether, four years after a crisis ends, $84 \%$ of our sample are considered democracies. Among this group of stable democracies, we found considerable learning effects as real credit growth from pre- to post-crisis fell by $6.87 \%$ points (see Table 1). Meanwhile, of the remaining autocracies (i.e., the stable autocracies), there was also a reduction in post-crisis credit growth but of a much smaller size (a reduction of $2.02 \%$ points). As differences in the outcome variable between these two time periods - before and after the crisis - reflect democratic transitions, the evidence presented here suggests that democratic transition plays an important role in affecting discipline from banking crises. Indeed, we found even larger discipline effects in countries that transitioned to democracy during and in the wake of a banking crisis, with an average $16.65 \%$ points reduction in credit growth from pre- to post-crisis. For more details on the pre- and post-crisis credit growth, please see table A.1 in the appendix.

\footnotetext{
${ }^{24}$ While our sample does not contain banking crises that are followed by democratic breakdowns, Russia's polity score did fall considerably after the 2008 crisis, suggesting that the regime became more authoritarian. Polity IV's data set places Russia just at the border between a democracy and autocracy a year ahead of the 2008 banking crisis. Russia appeared to be democratizing in the early 2000s due to fewer restrictions on which parties could compete in elections. Although Vladimir Putin was democratically reelected in 2004, since then, a process of authoritarian reversal has been observed. Given this narrative, and consistent with other cross-country data sets such as Varieties of Democracy, Freedom House, and Cheibub et al. (2010), we consider Russia an autocracy in both the pre- and post-crisis periods.
} 
Table 1. Summary Statistics: Changes in Credit Growth \& Political Regimes

\begin{tabular}{lccc} 
& $\begin{array}{c}\text { Stable Democracies } \\
(41)\end{array}$ & $\begin{array}{c}\text { Stable Autocracies } \\
(8)\end{array}$ & $\begin{array}{c}\text { Democratic } \\
\text { Transitions (10) }\end{array}$ \\
\hline Pre-crisis credit growth & $9.9 \%$ & $11.74 \%$ & $18.46 \%$ \\
Post-crisis credit growth & $3.03 \%$ & $9.72 \%$ & $1.97 \%$ \\
Difference (in \% points) & $-6.87 \%$ & $-2.02 \%$ & $-16.65 \%$
\end{tabular}

We created a summary of the data distribution for government turnovers and changes in credit growth in Table 2 below. Approximately 63\% (37 out of 59) of the banking crisis episodes in our sample were followed by a partisan turnover; out of this sub-set, slightly more than $50 \%$ involved a turnover to the left. Leftward partisan-turnovers on average experienced a smaller reduction in credit growth, compared to rightward turnovers (4.28\% points reduction, compared to $9.41 \%$ points). Nevertheless, the changes in credit growth for banking crisis episodes that were followed by a turnover are almost identical to those that involved no partisan turnovers (-7.87\% points compared to $-7.57 \%)$. There is thus little (or at best mixed) support that partisan turnovers influence post-crisis learning outcomes despite their frequency.

Table 2. Distribution of Government Turnover and Transition to Democracies

\begin{tabular}{ccccc} 
& N & $\begin{array}{c}\text { Average CG } \\
\text { pre-crisis }\end{array}$ & $\begin{array}{c}\text { Average CG } \\
\text { post-crisis }\end{array}$ & Difference \\
\hline Turnover (all) & 37 & $11.01 \%$ & $3.14 \%$ & $-7.87 \%$ \\
Turnover_left & 18 & $10.42 \%$ & $6.14 \%$ & $-4.28 \%$ \\
Turnover_right & 13 & $10.02 \%$ & $0.62 \%$ & $-9.41 \%$ \\
No turnovers & 22 & $12.28 \%$ & $4.71 \%$ & $-7.57 \%$
\end{tabular}

\subsection{Regression Results}

In this section, we present results from OLS regressions with clustered standard errors at the country level, per the equation presented in section 3. We use a democracy dummy measured at precrisis $\left(t_{s}-1\right)$ in column 1 of Table 3 and democracy at the post-crisis period $\left(t_{f}+4\right)$ in column 2 of Table 3. Column 3 estimates changes in credit growth from pre- to post-crisis periods using the concept of democratic transitions, where democratization is a variable which equals to one if the crisis episode involved a change in the country's political regime from autocracy to democracy, as well as if the country experienced substantial improvements in the polity2 score (+3 points or more). Columns 4 and 5 present sub-samples that exclude the crisis episodes that took place in and around the 2007-09 Global Financial Crisis (GFC). 
The results from Table 3 provide some support that a positive role is played by democracy in facilitating learning effects after a crisis, although our findings are highly dependent on the timing at which we consider a country to be democratic. When measured just prior to the crisis onset (one-year prior), as seen in column 1, democratic regimes experience no significant difference in changes in credit growth compared to authoritarian regimes, from pre- to post-crisis periods (veto players in column 1 follow the same rule, they are measured in the pre-crisis period, and during the post-crisis period for all others). However, when we measure the regimes four years after the crisis has ended, i.e. the first year of our post-crisis window, compared to autocracies, credit growth in the post-crisis period is $11.4 \%$ points lower in democracies and the difference is statistically significant at the $5 \%$ level. The difference in the results for the democracy dummy variable between columns 1 and 2 would therefore reflect the effects of democratic transitions on learning from crises. That is, countries that experienced a democratic transition (democratization) are significantly more likely to have a lower credit growth in the post-crisis magnitude, and the magnitude is slightly larger (12\% points). This finding also holds when we exclude episodes of the Global Financial Crisis (columns 4 and 5).

\section{Table 3. The effects of democracy, government turnovers and veto players on post-crisis changes} in credit growth

\begin{tabular}{|c|c|c|c|c|c|}
\hline VARIABLES & $\begin{array}{l}\text { (1) } \\
\text { Democracy- } \\
\text { at pre-crisis }\end{array}$ & $\begin{array}{c}(2) \\
\text { Dem at } \\
\text { post-crisis }\end{array}$ & $\begin{array}{c}\text { (3) } \\
\text { Dem } \\
\text { transition }\end{array}$ & $\begin{array}{c}(4) \\
\text { Dem at } \\
\text { post-crisis } \\
\text { w/o GFC } \\
\end{array}$ & $\begin{array}{c}(5) \\
\text { Dem } \\
\text { transition } \\
\text { w/o GFC }\end{array}$ \\
\hline Democracy dummy & $\begin{array}{c}1.463 \\
(7.159)\end{array}$ & $\begin{array}{c}-11.37 * * \\
(5.597)\end{array}$ & & $\begin{array}{c}-10.67 * \\
(5.446)\end{array}$ & \\
\hline Democratization & & & $\begin{array}{c}-12.16^{*} \\
(6.207)\end{array}$ & & $\begin{array}{c}-11.78^{* *} \\
(5.732)\end{array}$ \\
\hline Veto players & $\begin{array}{c}4.160 \\
(13.33)\end{array}$ & $\begin{array}{c}17.42 \\
(14.11)\end{array}$ & $\begin{array}{c}7.511 \\
(13.36)\end{array}$ & $\begin{array}{c}10.48 \\
(13.71)\end{array}$ & $\begin{array}{c}2.439 \\
(11.98)\end{array}$ \\
\hline Turnover left & $\begin{array}{c}4.400 \\
(5.243)\end{array}$ & $\begin{array}{c}6.981 \\
(4.861)\end{array}$ & $\begin{array}{c}4.292 \\
(4.708)\end{array}$ & $\begin{array}{l}10.23^{*} \\
(5.376)\end{array}$ & $\begin{array}{c}6.412 \\
(5.317)\end{array}$ \\
\hline Turnover right & $\begin{array}{c}-1.138 \\
(5.579)\end{array}$ & $\begin{array}{c}1.768 \\
(5.013)\end{array}$ & $\begin{array}{c}-2.789 \\
(5.128)\end{array}$ & $\begin{array}{c}4.158 \\
(6.665)\end{array}$ & $\begin{array}{l}-1.301 \\
(6.933)\end{array}$ \\
\hline Constant & $\begin{array}{c}-11.30 * * * \\
(4.006)\end{array}$ & $\begin{array}{l}-7.728 \\
(5.071)\end{array}$ & $\begin{array}{l}-9.658 \\
(7.012)\end{array}$ & $\begin{array}{l}-4.464 \\
(4.133)\end{array}$ & $\begin{array}{l}-5.379 \\
(5.214)\end{array}$ \\
\hline Observations & 59 & 59 & 59 & 41 & 41 \\
\hline R-squared & 0.030 & 0.091 & 0.109 & 0.118 & 0.140 \\
\hline
\end{tabular}

We found no strong support that government turnover (leftward or rightward), leads to a significant change in credit growth in the post-crisis period, consistent with the pattern discussed earlier 
in the descriptive statistics section. The turnover_left dummy is positive and significant at the $10 \%$ level, but only when we exclude the GFC crisis episodes from the sample. It may be possible that if a new government forms after a crisis, that government will not feel that they were responsible for contributing to the crisis, and therefore is subject to less political pressure for credit-curbing reforms. Therefore, partisan turnover may reduce political pressures for reforms. Similarly, we did not find significant evidence that veto players are associated with more discipline effects. Given that the independent variables examined here arguably have conflicting theoretical effects, those variables found to have no significant effect seem to have balanced out the positive and negative effects.

We perform two simple robustness checks. First, we replicate our results in Table 3 using a measure of real credit growth that takes into account year-fixed effects (Table A.2). In columns 1-4 of table A.2, the dependent variable is the year-adjusted changes in real credit growth, from pre- to postcrisis period. ${ }^{25}$ We obtain qualitatively similar results with this alternate measurement of the dependent variable as we did in the baseline results. Being a democracy before a financial crisis does not lead to any significant difference in credit growth in the post-crisis period as compared to an autocracy, but becoming a democracy after a financial crisis leads to a significantly lower rate of credit growth after the crisis. The democratization dummy variable is also significant and negative. That is, a democratic transition is associated with a lower reduction in post-crisis credit growth of $12 \%$ points and the estimated effect is significant at the $5 \%$ level (column 3, Table A.2.)

Second, we replicate our results for democratic transition using an alternative data set (Freedom House), following Acemoglu et al. (2019) and Lacroix et al. (2017), which operationalized a democratic transition as a change in the Freedom House index. ${ }^{26}$ That is, the status of the country's democratic system changed from 'not free' to 'partially free', partially free to 'free' or from not free to free. As seen in column 4 of Table A.2, countries that transitioned to democracies had a $12.4 \%$ points lower credit growth post-crisis compared to those that did not experience any political transitions. However, when the dependent variable does not account for time-fixed effects, the democratization variable using data from Freedom House (column 5, Table A. 2), this coefficient is not statistically significant.

\footnotetext{
${ }^{25}$ Instead of including a dummy variable for each year in the data set (i.e., year dummies), we subtract each country-year credit growth value with the average credit growth in the relevant year to avoid having too many regressors. For example, real credit growth in Argentina (1990) is subtracted by the average 1990 real credit growth value for all the countries in our sample.

${ }^{26}$ We note that there is considerable disagreement about what constitutes democratic transitions based on Polity2 data and based on Freedom House data as there is only a 50\% overlap in our sample. Freedom House focuses on civil liberties, while Polity2 emphasizes on electoral aspects of democracy.
} 


\subsection{Marginal Effects Analysis of Veto Players on Changes in Credit Growth}

We add two alternative specifications using quadratic and interaction terms in Table 4 below, to test for the non-linear (column 1) as well as indirect effects (column 2) of veto players. Allowing for non-linear effects of the veto players variable does not alter the results found in the previous sub-section of the baseline results. The veto players variable in linear and quadratic forms are not significant, while the democracy dummy (measured at the post-crisis period) is negative and significant at the 10\% level.

\section{Table 4. Non-linear and Indirect Effects of Veto Players on Post-Crisis Credit Growth}

\begin{tabular}{|c|c|c|}
\hline VARIABLES & $\begin{array}{c}(1) \\
\text { Veto Players } \\
\text { Quadratic }\end{array}$ & $\begin{array}{c}\text { (2) } \\
\text { Democracy x Veto Players }\end{array}$ \\
\hline Democracy at post-crisis dummy & $\begin{array}{l}-10.15^{*} \\
(5.875)\end{array}$ & $\begin{array}{l}-20.43^{* *} \\
(9.767)\end{array}$ \\
\hline Democracy x Veto Players & & $\begin{array}{c}29.84 \\
(26.11)\end{array}$ \\
\hline Veto players & $\begin{array}{c}-8.879 \\
(33.07)\end{array}$ & $\begin{array}{l}-4.439 \\
(17.94)\end{array}$ \\
\hline Veto players $\wedge 2$ & $\begin{array}{c}35.48 \\
(35.97)\end{array}$ & \\
\hline Turnover_left & $\begin{array}{c}6.677 \\
(5.021)\end{array}$ & $\begin{array}{c}6.094 \\
(4.997)\end{array}$ \\
\hline Turnover_right & $\begin{array}{c}1.198 \\
(5.295)\end{array}$ & $\begin{array}{c}0.842 \\
(5.168)\end{array}$ \\
\hline Constant & $\begin{array}{l}-4.746 \\
(6.137)\end{array}$ & $\begin{array}{l}-1.589 \\
(4.052)\end{array}$ \\
\hline Observations & 59 & 59 \\
\hline R-squared & 0.099 & 0.110 \\
\hline
\end{tabular}

The effects of democracy conditional on the number of veto players on our dependent variable is analyzed in column 2 of Table 4 . With interaction term models, the coefficients on the individual variables lose their traditional meaning and it is considered good practice to interpret the conditional effects through marginal analysis. While democracies are likely to face pressure from constituents to institute reforms after a crisis, constraints imposed by higher levels of veto players may weaken this effect. Although the interaction term between democracy and veto players is not significant, note that this term only gives us marginal effects of democracy evaluated at the mean. The marginal effects plots in Figure 1 allows the effects of the democracy on changes in credit growth to vary according to the number of veto players. 
Figure 1. Marginal Effects of Democracy on Changes in Post-Crisis Credit Growth

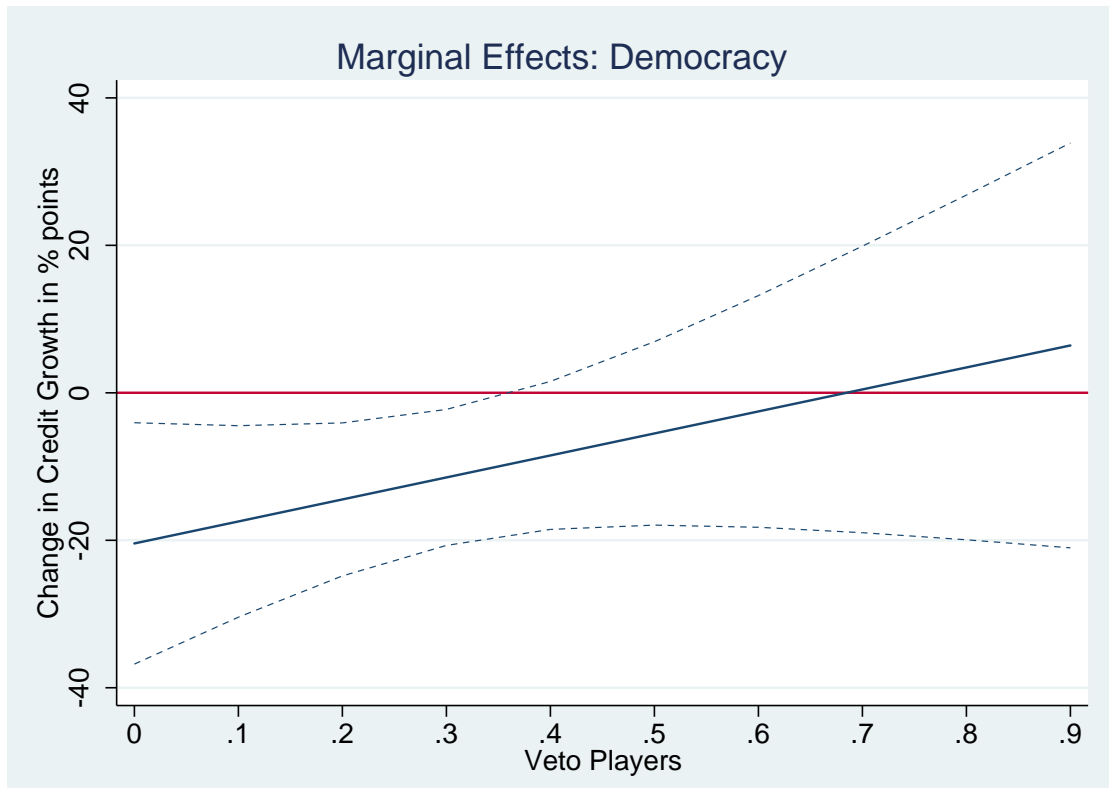

Figure 1 suggests that while democracies experience a larger reduction in credit growth the effects are decreasing (i.e., the learning effect becomes weaker as seen by the smaller reduction in credit growth) as the number of veto players increases. When the number of veto players are low (about $0-0.3$ ), democracies experience significantly lower credit growth after a crisis has subsided. Above the veto players value of 0.3 , the difference between a democracy and a non-democracy in reducing credit growth is not statistically significant. ${ }^{27}$ Thus, there is some support to the idea that above a threshold a higher number of veto players make reforms more difficult and reduces the post-crisis effective learning trajectory of democracies.

\subsection{The Role of Regulation and Supervision}

A general testing of the various mechanisms through which effective learning may operate lies beyond the scope of this paper. Here, we explore evidence on one of the most important mechanisms: regulatory reform. In our earlier study (Amri et al. 2017) we found that improvements in regulation and supervision tended to follow banking crises. Here, we ask whether such changes in financial regulation and supervision (FRS) scores are associated with political regimes or regime transitions. In Table 5, we

\footnotetext{
${ }^{27}$ An interpretation of this may be related to the ease of instituting disciplining policy reforms. With fewer constraints on democracies political pressure to institute disciplining reforms may more effectively generate policy reform, curbing credit growth.
} 
compare changes in FRS scores (from pre- to post-crisis) between democracies vs autocracies, taking into account both the state of political regimes and regime transitions.

\section{Table 5. Changes in Financial Regulation and Supervision (FRS) Score \& Political Regimes}

\begin{tabular}{lcccc} 
& $\mathrm{N}$ & Pre-crisis FRS & Post-crisis FRS & Difference \\
\hline Democracy (autocracy) at $\mathrm{t}_{\mathrm{s}}-1$ & $38(17)$ & $0.485(0.091)$ & $0.652(0.262)$ & $0.166(0.176)$ \\
Democracy (autocracy) at $\mathrm{t}_{\mathrm{f}}+4$ & $46(9)$ & $0.401(0.172)$ & $0.572(0.333)$ & $0.171(0.161)$ \\
Democratization (from $\mathrm{t}_{s}-1$ to $\left.\mathrm{t}_{\mathrm{f}}+4\right)$ & 9 & 0.012 & 0.209 & 0.197 \\
All & 55 & 0.363 & 0.533 & 0.169 \\
\hline
\end{tabular}

Note: FRS is a score between $0-1$, with higher scores reflecting more regulation. These are measured along four dimensions: stringency of capital adequacy ratios, independence of financial regulatory authorities, effectiveness of on-site and off-site monitoring, and the universality of types of financial institutions that fall under the purview of the official supervisory agency. The data originally comes from Abiad et al. (2010) and was later extended by Denk and Gomes (2017) for almost all the crisis-hit countries in our sample. Only 55 out of our 59 cases had available FRS data for the relevant time-windows.

Table 5 suggests that democracies experience a higher increase in FRS scores in the post-crisis period compared to autocracies, but only for stable democracies and those that transitioned to democracies from the pre- to post-crisis periods. However, the difference does not seem to be that large (0.171 compared to 0.161$)$. It should be noted, however, that democracies tend to start out with a higher FRS score pre-crisis compared to autocracies. Consistent with earlier results, the largest increase in FRS scores appears in the group that experienced democratic transitions, compared to stable autocracies and stable democracies. This provides support for the possibility that one way in which democratic transitions may lead to more effective learning from financial crises is by creating conditions which are favorable for reforms that improve financial regulation and supervision after a crisis. ${ }^{28}$ Additionally, we did not find any notable correlation between initial levels of FRS and the changes in the FRS in the postcrisis period.

\section{Conclusion and Directions for Further Research}

In a large $N$ study of banking crises occurring between 1977 and 2011, we test several domestic factors that may influence effective learning from banking crises: political regimes, veto players, and government turnovers. We found several notable results. First, we find support for the "democracy facilitates learning” hypothesis although this applies only to democracies after the crisis. Democracy

\footnotetext{
28 These findings are consistent with Saka et al. (2020), who found banking supervision is higher 4-7 years after the crisis compared to the immediate years after the banking crisis, even though the authors note a reversal of other areas of financial reform post-crisis, in particular, financial liberalization.
} 
prior to the crises is found to have no significant effect. On average, we estimate that democracies in the post-crisis period experience a significantly greater drop in rates of credit expansion in post-crisis periods compared to autocracies, and indeed, we found very little aggregate learning effects in autocracies.

This is consistent with our result that democratic transitions appear to have a strong effect on lowering post crisis rates credit growth. Democratization matters, and it seems to matter more than the level of democracy itself. One potential explanation for this finding is the presence of declining marginal effects of democracy on post-crisis discipline effects. In the initial stages of the transition there was more momentum and thus more incentives (including electoral incentives) for reform, while this momentum becomes less strong as countries undergo the process of democratic consolidation. Other potential explanations could be a weakening of old special interests in finance or that new leaders have truly learned the lessons that crises are economically and politically costly. However, we would also need to look at alternative explanations unrelated to regime change (for example, were these crises are more severe to begin with, thus a larger correction in the post-crisis period).

Government turnovers do not appear to have major effects. All of the coefficients indicate that left turnovers are associated with increased credit growth in the post crisis periods, but only one of the coefficients is significant. Right turnovers are evenly balanced with increases and decreases but none are significant. A similar conclusion holds for the effects of veto players on post-crisis credit growth. None of the coefficients of the veto players variable, whether in linear or non-linear form, have a significant effect on changes in credit growth from pre- to post-crisis periods. However, there is some support for the idea that the number of veto players above a threshold affects post-crisis learning outcomes by making reforms more difficult to obtain and thus dampening the effects of democracy on post-crisis credit growth.

There are a number for directions for fruitful further research. One is to investigate the effects of additional political and institutional variables such as the rule of law and the strength and competence of governments. In future research, we plan to begin with investigation of the effects of variables that may impose effective learning from outside of the domestic political process, specifically the role of central bank independence, exchange rate regimes and programs with the International Monetary Fund. It will also be fruitful to look at different proxies for learning and different types of crises ${ }^{29}$ as well as effects on the frequency of subsequent crises. ${ }^{30}$ We can also do more with large $\mathrm{N}$ studies to investigate various

\footnotetext{
${ }^{29}$ Chiu, Meyer, and Willett (2020) have begun a study of learning from currency crises.

${ }^{30}$ For an early study of this see Aizenman and Noy (2013). They use only one formulation of the learning window. The robustness of their results to different measures should be explored.
} 
channels through which learning effects may occur. For example, we can investigate proxies for reforms in financial regulation and supervision.

However how far large $N$ studies can go in this direction has limits. There is a strong need for detailed case studies that can look in much more detail at the degree to which different types of actors do or do not learn, and for those who do learn, the factors that influence whether they are able to convert their learning into institutional reforms through the political process and/or the development of more prudent behavior by the private sector and monetary and regulatory authorities. ${ }^{31}$

${ }^{31}$ Such case studies can also investigate what different actors perceive that the lessons of crises are. For example, in the US after the subprime financial crisis those on the far right put emphasis on quite different factors as the major cause of the crisis than did those on the far left.

Bookstaber (2019). 


\section{References}

Abiad, A., \& Mody, A. (2005). “Financial Reform: What Shakes It, What Shapes It?” American Economic Review 95 (1): 66-88.

Aizenman, J., \& Noy, I. (2013). "Macroeconomic Adjustment and the History of Crises in Open Economies.” Journal of International Money and Finance, 38: 41-58.

Aldasoro, I, Borio, C., \& Drehmann, M. (2018). "Early Warning Indicators of Banking Crises: Expanding the Family.” BIS Quarterly Review, March 2018.

Amri, P., Prabha, P., \& Wihlborg, C. (2012). "What Makes Credit Growth Harmful? Evidence from Banking Crises .” Available at SSRN: http://ssrn.com/abstract=2186569 or doi: http://dx.doi.org/10.2139/ssrn.2186569.

Amri, P., \& Willett, T.D. (2017). "Policy Inconsistencies and the Political Economy of Currency Crises.” Journal of International Commerce, Economics and Policy 8 (1): 175-179.

Amri, P., Chiu, E.M.P., Richey, G.M., \& Willett, T.D. (2017). “Do Financial Crises Discipline Future Credit Growth?” Journal of Financial Economic Policy 9 (3): 284-301.

Antoniades, A., \& Calomiris, C. W. (2020). Mortgage market credit conditions and US Presidential elections. European Journal of Political Economy, 101909.

Angelides, P. and Thomas, B. (2011). The Financial Crisis Inquiry Report: Final Report of the National Commission on the Causes of the Financial and Economic Crisis in the United States. Government Printing Office.

Angkinand, A.P., \& Willett, T.D. (2008) "Political Influences on the Cost of Banking Crises in Emerging Market Economies: Testing the U-Shaped Veto Player Hypothesis.” Macroeconomics and Finance in Emerging Market Economies 1 (2): 279-297.

Bardhan, P. (1998). "Epilogue on the Political Economy of Reform in India.” In The Political Economy of Development in India.” Delhi: Oxford University Press.

Bartels, L.M. (2014). “Ideology and Retrospection in Electoral Responses to the Great Recession.” In Bermeo, N. and Bartels, L.M. (eds.) Mass Politics in Tough Times: Opinions, Votes, and Protest in the Great Recession. Oxford: Oxford University Press.

Beck, T., Demirguc-Kunt, A., \& Levine, R. (2006). "Bank Concentration, Competition, and Crises: First Results.” Journal of Banking and Finance 30 (5): 1581-1603.

Belanger, E., \& Nadeau, R. (2014). “Economic Crisis, Party Confidence, and the Economic Vote.” Acta Polit 49: 462-485.

Berger, A. N., \& Udell, G. F. (2004). The institutional memory hypothesis and the procyclicality of bank lending behavior. Journal of financial intermediation, 13(4), 458-495. 
Bookstaber, R.M. (2019). “The End of Theory: Financial Crises, the End of Economics, and the Sweep of Human Interaction.” Princeton: Princeton University Press.

Bordo, M.D. (2007). “Growing up to Financial Stability.” NBER Working Paper Series No. 12993.

Brambor, T., \& and Lindvall, J. (2012). “The Ideology of Heads of Government, 1870-2012.” European Political Science 17, 211-222.

Broz, J.L. (2013). “Partisan Financial Cycles.” Politics in the New Hard Times: The Great Recession in Comparative Perspective. Edited by David L. Lake and Miles Kahler. Ithaca, NY: Cornell University Press, 2013.

Calomiris, C.W., \& Haber, S. (2014). "Fragile by Design: Banking Crises, Scarce Credit, and Political Bargains.” Princeton: Princeton University Press.

Calvo, D., Crisanto, J.C., Hohl, S., \& Gutiérrez, O.P. (2018). "Financial Supervisory Architecture: What has Changed after the Crisis?" FSI Insights on Policy Implementation, 8.

Campello, D. (2014). “The Politics of Financial Booms and Crises: Evidence from Latin America.” Comparative Political Studies, 47(5): 260-286.

Campos, N.F., Hsiao, C. \& Nugent, J.B. (2010). “Crises, What Crises? New Evidence on the Relative Roles of Political and Economic Crises in Begetting Reforms. The Journal of Development Studies, 46(10): 1670-1691.

Caprio, G. \& Klingebiel, D. (1996). “Bank Insolvency: Bad Luck, Bad Policy, or Bad Banking?” Annual World Bank Conference on Development Economics. Washington D.C. World Bank, 79104.

Cavallo, A.F., \& Cavallo, E. A. (2010). “Are Crises Good for Long-Term Growth? The Role of Political Institutions.” Journal of Macroeconomics 32(3): 838-857.

Cheibub, J., Gandhi, J., \& Vreeland, R. (2010). “Democracy and Dictatorship Revisited.” Public Choice 143(2): 67-101.

Cox, G.W., \& McCubbins, M.D. (2001). “The Institutional Determinates of Economic Policy Outcomes.” In Presidents, Parliaments, and Policy, ed. Stephen Haggard and Matthew D. McCubbins. Cambridge: Cambridge University Press.

Cukierman, A. \& Tomassi, M. (1998). “When Does it Take Nixon to Go to China?” American Economic Review 88: 180-197.

Davies, H. (2010) “The Financial Crisis: Who is to Blame?” Malden, Massachusetts, United States: Polity Press.

Dell'Ariccia, G., Detragiache, E. \& Rajan, R. (2008). “The Real Effect of Banking Crises.” Journal of Financial Intermediation 17(1): 89-112.

Drazen, A. (2002). “Political Economy in Macroeconomics.” Princeton, United States: Princeton University Press. 
Drehman, M. \& Yetman, J. (2018). "Why you should Use the Hodrik-Prescott Filter-at Least to Generate Credit Gaps.” BIS Working Paper No. 744.

Funke, M., Schularick, M., \& Trebesch, C. (2016). “Going to Extremes: Politics after Financial Crises, 1870-2014.” European Economic Review 88, 227-260.

Gelbach, S., \& Malesky, E.J. (2010). “The Contribution of Veto Players to Economic Reform.” The Journal of Politics 72(4): 957-975.

Gennaioli, N., \& Shleifer, A. (2018). A Crisis of Beliefs. Princeton University Press.

Gilardi, F. (2010). Who learns from what in policy diffusion processes?. American Journal of Political Science, 54(3), 650-666.

Giuliano, P., Mishra, P., \& Spilimbergo, A. (2013). “Democracy and Reforms.” American Economic Journal: Macroeconomics 5(4): 179-204.

Ha, E., \& Kang, M. K. (2015). Government Policy Responses to Financial Crises: Identifying Patterns and Policy Origins in Developing Countries. World Development, 68, 264-281.

Haber, S.H. \& Musacchio, A. (2013). “These are the Good Old Days: Foreign Entry and the Mexican Banking System.” NBER Working Paper No. 18713.

Henisz, W. J. (2000). "The Institutional Environment for Economic Growth." Economics and Politics 12 (1): 1-31.

Horowitz, S., Hoff, K., \& Milanovic, B. (2009). “Government Turnover; Concepts, Measures and Applications.” European Journal of Political Research 48 (1): 107-129.

Kay, J. (2015). “Other People’s Money: The Real Business of Finance.” New York: Public Affairs.

Keefer, P. (2001). “When Do Special Interests Run Rampant? Disentangling the Role of Banking Crises in Elections, Incomplete Information, and Checks and Balances.” World Bank Policy Research Working Paper No. 2543.

Kern, A., Reinsberg, B., \& Rau-Göhring, M. (2019). IMF conditionality and central bank independence. European Journal of Political Economy, 59, 212-229.

Kern, A., \& Amri, P. (2020). “Political Credit Cycles.” Economics \& Politics. 2020;00:1-33. https://doi.org/10.1111/ecpo.12158

King, M. (2016). “The End of Alchemy: Money, Banking, and the Future of the Global Economy.” New York: Norton.

Kouevi-Gath, B., Meon, P.G., \& Weill, L. (2019). “Do Banking Crises Improve Democracy?” Public Choice, 1-34.

Laeven, L., \& Valencia, F. (2020). “Systemic Banking Crises Database: A Timely Update in Covid-19 Times.” CEPR Discussion Paper No. DP14569.

Lewis-Beck, M.S., \& Lobo, M.C. (2017). “The Economic Vote: Ordinary vs. Extraordinary Times.” In Arzheimer, K., Evans, J., and Lewis-Beck, M.S. (eds.) The SAGE Handbook of Electoral Behavior. London: Sage Publications, vol. 2: 606-629. 
Lim, J., \& Minne, G. (2014). “Learning from Financial Crises.” World Bank Policy Research Working Paper No. 6838. Available at SSRN: https://ssrn.com/abstract=2423150.

Lipscy, P. (2011). “Democracy and Financial Crisis.” Paper Presented at the 2011 Annual Meeting of the International Political Economy Society.

MacIntyre, A. (2001). "Institutions and Investors: The Politics of the Economic Crisis in Southeast Asia.” International Organization 55 (1): 81-122.

Marshall, M. G., Gurr, T. R., \& Jaggers, K. (2018). Political Regime Characteristics and Transitions, 1800'2017. Center for Systemic Peace. www. systemicpeace. org.

Meseguer, C. (2006). Learning and economic policy choices. European Journal of Political Economy, 22(1), 156-178.

Meyer, J., Chiu, E,, \& Willett, Y. (2020). “Do Currency crises reduce the probability of Future crises?” In draft

Mian, A., Sufi, A., \& Trebbi, F. (2014). "Resolving Debt Overhang: Political Constraints in the Aftermath of Financial Crises.” American Economic Journal: Macroeconomics 6 (2):1-28.

Moschella, M. \& Tsingou, E. (2013). "Regulating Finance after the Crisis: Unveiling the Different Dynamics of the Regulatory Process.” Regulation and Governance 7 (4): 407-416.

Mukherjee, B., Yadav, V., \& Béjar, S. (2014). Electoral particularism, bank concentration, and capital account liberalization in developing democracies. Comparative Political Studies, 47(6), 851-877.

Murillo, M.V., \& Martinez-Gallardo, C. (2007). "Political Competition and Policy Adoption: Market Reforms in Latin American Public Utilities.” American Journal of Political Science 51(1): 120139.

Reinhart, C. \& Rogoff, K. (2009). This Time is Different. Princeton University Press, Princeton, NJ.

Rodrik, D, (1999). “The Asian Financial Crisis and the Virtues of Democracy.” Challenge 42 (4): 4459.

Rodrik, D, (2000). “Participatory Politics, Social Cooperation, and Economic Stability.” American Economic Review 90 (2): 140-144.

Rosas, G. (2009). "Curbing Bailouts: Bank Crises and Democratic Accountability in Comparative Perspective.” University of Michigan Press.

Rosas, G., Aguilera, G. \& Ward, D. (2013). "After the Storm: How Political Institutions Affect Financial Governance in the Wake of Banking Crisis.” EPSA 2013 Annual General Conference Paper 837.

Schularick, M., \& Taylor, A. M. (2012). "Credit Booms Gone Bust: Monetary Policy, Leverage Cycles, and Financial Crises, 1870-2008.” American Economic Review 102(2): 1029-61. 
Simmons, B. A., Dobbin, F., \& Garrett, G. (2006). Introduction: The international diffusion of liberalism. International Organization: 781-810.

Takats, E., \& Upper, C. (2014). “Credit and Growth after Financial Crises.” BIS Working Paper No. 416.

Tomassi, M. (2004). "Crisis, Political Institutions and Policy Reform: The Good, the Bad, and the Ugly.” Annual World Bank Conference on Economic Development.

Waelti, S. (2015). Financial Crisis Begets Financial Reform? The Origin of the Crisis Matters,” European Journal of Political Economy 40: 1-15.

Yu, M. (2005). “Trade Globalization and Political Liberalization: A Gravity Approach.” Unpublished Manuscript, University of California, Davis.

\section{APPENDIX}


A1. List of Countries and Years in the sample (with positive pre-crisis credit growth), and Partisan Government Turnover

\begin{tabular}{|c|c|c|c|c|c|c|}
\hline No. & Country & $\begin{array}{c}\text { Banking } \\
\text { Crisis } \\
\text { Start }\end{array}$ & $\begin{array}{c}\text { Banking } \\
\text { Crisis } \\
\text { End }\end{array}$ & $\begin{array}{c}\text { Pre Crisis } \\
\text { Average } \\
\text { Credit } \\
\text { Growth }\end{array}$ & $\begin{array}{c}\text { Post Crisis } \\
\text { Average } \\
\text { Credit } \\
\text { Growth }\end{array}$ & $\begin{array}{c}\text { Before-After } \\
\text { Difference }\end{array}$ \\
\hline 1 & Argentina & 1980 & 1982 & $9.75 \%$ & $-1.69 \%$ & $-11.44 \%$ \\
\hline 2 & Argentina & 2001 & 2003 & $4.69 \%$ & $14.89 \%$ & $10.20 \%$ \\
\hline 3 & Austria & 2008 & 2012 & $5.29 \%$ & $1.19 \%$ & $-4.10 \%$ \\
\hline 4 & Belgium & 2008 & 2012 & $5.20 \%$ & $5.63 \%$ & $0.43 \%$ \\
\hline 5 & Bolivia & 1994 & 1994 & $22.68 \%$ & $6.52 \%$ & $-16.17 \%$ \\
\hline 6 & Brazil & 1994 & 1998 & $6.88 \%$ & $1.48 \%$ & $-5.41 \%$ \\
\hline 7 & Burkina Faso & 1990 & 1994 & $9.72 \%$ & $14.08 \%$ & $4.37 \%$ \\
\hline 8 & Chile & 1981 & 1985 & $43.93 \%$ & $4.14 \%$ & $-39.79 \%$ \\
\hline 9 & China & 1998 & 1998 & $9.16 \%$ & $13.99 \%$ & $4.83 \%$ \\
\hline 10 & Colombia & 1982 & 1982 & $9.12 \%$ & $-5.97 \%$ & $-15.08 \%$ \\
\hline 11 & Colombia & 1998 & 2000 & $7.91 \%$ & $11.17 \%$ & $3.26 \%$ \\
\hline 12 & Costa Rica & 1987 & 1991 & $4.76 \%$ & $2.88 \%$ & $-1.88 \%$ \\
\hline 13 & Costa Rica & 1994 & 1995 & $7.74 \%$ & $19.25 \%$ & $11.50 \%$ \\
\hline 14 & Denmark & 2008 & 2009 & $10.41 \%$ & $-0.99 \%$ & $-11.40 \%$ \\
\hline 15 & Dom Republic & 2003 & 2004 & $11.76 \%$ & $8.10 \%$ & $-3.66 \%$ \\
\hline 16 & Ecuador & 1982 & 1986 & $6.80 \%$ & $-35.11 \%$ & $-41.91 \%$ \\
\hline 17 & Egypt & 1980 & 1980 & $13.42 \%$ & $5.42 \%$ & $-8.00 \%$ \\
\hline 18 & Finland & 1991 & 1995 & $12.18 \%$ & $5.93 \%$ & $-6.25 \%$ \\
\hline 19 & France & 2008 & 2009 & $7.23 \%$ & $0.07 \%$ & $-7.16 \%$ \\
\hline 20 & Greece & 2008 & 2012 & $13.09 \%$ & $-5.55 \%$ & $-18.64 \%$ \\
\hline 21 & Hungary & 2008 & 2012 & $12.05 \%$ & $-0.70 \%$ & $-12.75 \%$ \\
\hline 22 & India & 1993 & 1993 & $2.01 \%$ & $5.95 \%$ & $3.95 \%$ \\
\hline 23 & Indonesia & 1997 & 2001 & $12.14 \%$ & $10.21 \%$ & $-1.93 \%$ \\
\hline 24 & Ireland & 2008 & 2012 & $19.94 \%$ & $-3.98 \%$ & $-23.92 \%$ \\
\hline 25 & Israel & 1983 & 1986 & $0.13 \%$ & $5.02 \%$ & $4.88 \%$ \\
\hline 26 & Italy & 2008 & 2009 & $7.20 \%$ & $-3.08 \%$ & $-10.28 \%$ \\
\hline 27 & Jamaica & 1996 & 1998 & $1.53 \%$ & $3.39 \%$ & $1.85 \%$ \\
\hline 28 & Japan & 1997 & 2001 & $1.32 \%$ & $0.60 \%$ & $-0.73 \%$ \\
\hline 29 & Jordan & 1989 & 1991 & $4.80 \%$ & $6.22 \%$ & $1.42 \%$ \\
\hline 30 & Korea & 1997 & 1998 & $10.94 \%$ & $8.14 \%$ & $-2.80 \%$ \\
\hline 31 & Madagascar & 1988 & 1988 & $5.64 \%$ & $-1.35 \%$ & $-6.99 \%$ \\
\hline 32 & Malaysia & 1997 & 1999 & $19.69 \%$ & $4.77 \%$ & $-14.92 \%$ \\
\hline 33 & Mexico & 1994 & 1996 & $23.43 \%$ & $-7.58 \%$ & $-31.01 \%$ \\
\hline 34 & Morocco & 1980 & 1984 & $3.18 \%$ & $5.65 \%$ & $2.47 \%$ \\
\hline 35 & Nepal & 1988 & 1988 & $11.68 \%$ & $13.66 \%$ & $1.98 \%$ \\
\hline
\end{tabular}




\begin{tabular}{|c|c|c|c|c|c|c|}
\hline 36 & Netherlands & 2008 & 2009 & $4.18 \%$ & $-0.70 \%$ & $-4.88 \%$ \\
\hline 37 & Nigeria & 2009 & 2012 & $32.33 \%$ & $-8.78 \%$ & $-41.12 \%$ \\
\hline 38 & Norway & 1991 & 1993 & $3.48 \%$ & $10.54 \%$ & $7.06 \%$ \\
\hline 39 & Paraguay & 1995 & 1995 & $16.17 \%$ & $-1.28 \%$ & $-17.44 \%$ \\
\hline 40 & Peru & 1983 & 1983 & $20.02 \%$ & $-11.22 \%$ & $-31.25 \%$ \\
\hline 41 & Philippines & 1983 & 1986 & $5.07 \%$ & $5.18 \%$ & $0.11 \%$ \\
\hline 42 & Philippines & 1997 & 2001 & $24.97 \%$ & $0.93 \%$ & $-24.04 \%$ \\
\hline 43 & Portugal & 2008 & 2012 & $6.35 \%$ & $-4.53 \%$ & $-10.88 \%$ \\
\hline 44 & Russia & 2008 & 2009 & $26.52 \%$ & $8.50 \%$ & $-18.02 \%$ \\
\hline 45 & Spain & 2008 & 2012 & $16.84 \%$ & $-3.74 \%$ & $-20.58 \%$ \\
\hline 46 & Sri Lanka & 1989 & 1991 & $3.81 \%$ & $39.10 \%$ & $35.30 \%$ \\
\hline 47 & Sweden & 1991 & 1995 & $12.44 \%$ & $24.69 \%$ & $12.26 \%$ \\
\hline 48 & Sweden & 2008 & 2009 & $9.50 \%$ & $3.76 \%$ & $-5.74 \%$ \\
\hline 49 & Switzerland & 2008 & 2009 & $6.09 \%$ & $3.13 \%$ & $-2.96 \%$ \\
\hline 50 & Thailand & 1983 & 1983 & $2.48 \%$ & $17.22 \%$ & $14.73 \%$ \\
\hline 51 & Thailand & 1997 & 2000 & $18.14 \%$ & $4.44 \%$ & $-13.70 \%$ \\
\hline 52 & Turkey & 2000 & 2001 & $3.33 \%$ & $25.21 \%$ & $21.88 \%$ \\
\hline 53 & Uganda & 1994 & 1994 & $20.08 \%$ & $11.67 \%$ & $-8.41 \%$ \\
\hline 54 & Ukraine & 2008 & 2010 & $37.98 \%$ & $-14.45 \%$ & $-52.43 \%$ \\
\hline 55 & United Kingdom & 2007 & 2011 & $8.69 \%$ & $0.21 \%$ & $-8.48 \%$ \\
\hline 56 & United States & 1988 & 1988 & $6.37 \%$ & $-2.49 \%$ & $-8.86 \%$ \\
\hline 57 & United States & 2007 & 2011 & $6.50 \%$ & $4.35 \%$ & $-2.14 \%$ \\
\hline 58 & Uruguay & 1981 & 1985 & $22.76 \%$ & $-5.74 \%$ & $-28.49 \%$ \\
\hline 59 & Uruguay & 2002 & 2005 & $11.31 \%$ & $1.55 \%$ & $-9.75 \%$ \\
\hline
\end{tabular}


Table A.2 Robustness Tests: time-fixed effects and alternate measure of democratic transitions

\begin{tabular}{lccccc}
\hline VARIABLES & $\begin{array}{c}(1) \\
\text { Dem at pre- } \\
\text { crisis }\end{array}$ & $\begin{array}{c}(2) \\
\text { Dem at post- } \\
\text { crisis }\end{array}$ & $\begin{array}{c}(3) \\
\text { Democratic } \\
\text { transition }\end{array}$ & $\begin{array}{c}(4) \\
\text { Democratic } \\
\text { Transition } \\
\text { (Freedom } \\
\text { House) }\end{array}$ & $\begin{array}{c}(5) \\
\text { Democratic } \\
\text { Transition } \\
\text { (Freedom } \\
\text { House) } 2\end{array}$ \\
\hline Democracy dummy & 2.377 & $-9.900^{*}$ & & & \\
Democratization & $(6.322)$ & $(5.541)$ & & & \\
Veto players & & & $-12.15 * *$ & $-12.36 * *$ & -8.349 \\
& 4.012 & 16.65 & $(5.410)$ & $(5.002)$ & $(5.617)$ \\
turnover_left & $(11.93)$ & $(13.28)$ & $(12.83)$ & 5.130 & 6.365 \\
& 1.923 & 4.439 & 2.027 & 3.860 & $(13.63)$ \\
turnover_right & $(4.890)$ & $(4.577)$ & $(4.354)$ & $(4.661)$ & 5.712 \\
& -2.786 & 0.206 & -4.095 & -3.693 & -1.671 \\
Constant & $(5.192)$ & $(4.591)$ & $(4.675)$ & $(4.552)$ & $(5.067)$ \\
& $-8.446 * *$ & -5.220 & -6.462 & -5.795 & -10.31 \\
Year fixed-effects & $(3.865)$ & $(5.357)$ & $(7.050)$ & $(6.791)$ & $(7.173)$ \\
Observations & Yes & Yes & Yes & Yes & No \\
R-squared & 59 & 59 & 59 & 59 & 59 \\
& 0.024 & 0.075 & 0.110 & 0.117 & 0.071 \\
\hline
\end{tabular}

Robust standard errors in parentheses, ${ }^{* * *} \mathrm{p}<0.01,{ }^{* *} \mathrm{p}<0.05,{ }^{*} \mathrm{p}<0.1$ 